\title{
Нелинейно-оптические свойства углеродных нанотрубок с электрохимическим легированием для насыщающихся поглотителей в волоконных лазерах
}

\author{
Ю. Гладуш ${ }^{1,2, *}$, А. Мкртчан ${ }^{1}$, В. Яковлев ${ }^{1}$, Д. Копылова ${ }^{1}$, А. Хегай ${ }^{3}$, \\ М. Мелькумов ${ }^{3}$, М. Бурданова ${ }^{4}$, А. Насибулин ${ }^{1,5}$ \\ ${ }^{1}$ Сколковский институт науки и технологий, Россия \\ ${ }^{2}$ Институт спектроскопии РАН, Россия \\ ${ }^{3}$ Национальный центр волоконной оптики, Россия

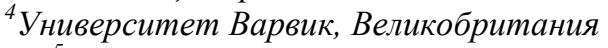 \\ ${ }^{5}$ Университет Аалто, Финляндия \\ *E-mail: y.gladush@skoltech.ru
}

DOI:10.31868/RFL2018.152-153

Известно, что углеродные нанотрубки могут быть использованы в качестве насыщающегося поглотителя для волоконных лазеров. Стандартный подход предполагает создание композитного материала на основе нанотрубок и полимера, который зажимается между двух коннекторов. Другой подход предполагает осаждение нанотрубок из жидкости напрямую на поверхность волокна - лицевую грань, полированное или тейпированное волокно - $\mathrm{c}$ помощью термодиффузии или других методов. Любой из этих подходов предполагает, кроме непосредственно роста углеродных нанотрубок, дополнительные шаги по приготовлению суспензии, ее очистке и осаждению нанотрубок. В данной работе для изготовления насыщающегося поглотителя мы используем углеродные нанотрубки, выращенные методом аэрозольного синтеза. Такие трубки собирается на целлюлозный фильтр непосредственно на выходе из реактора и могут быть перенесены на любую поверхность методом сухого переноса. Ранее были продемонстрированы насыщающиеся поглотители, изготовленные с применением данной техники, на внешних зеркалах и на коннекторах [1]. В этой работе мы используем метод сухого переноса для изготовления насыщающихся поглотителей на полированном волокне.

Данные пленки углеродных нанотрубок не содержат полимер или сурфактант, это делает электрохимические легирование нанотрубок с помощью ионной жидкости исключительно эффективным. Такой гейтинг позволяет сдвигать уровень ферми под действием небольшого напряжения и, таким образом, управлять поглощение углеродных нанотрубок. В работе мы используем технику возбуждения-зондирования для изучения поведения нелинейного поглощения в углеродных нанотрубках в зависимости от степени легирования. Мы показываем, что электрохимическое легирование приводит к уменьшению нелинейного просветления и увеличению скорости релаксации. Далее мы используем насыщающийся поглотитель на основе углеродных нанотрубок с ионной жидкостью в эрбиевом волоконном лазере. Мы демонстрируем, что, подавая напряжение на углеродные нанотрубки мы можем осуществлять переключение между различными видами импульсной генерации. В схеме с анормальной полной дисперсией мы демонстрируем переключение между импульсами 400 фс в режиме синхронизации мод и 2 мкс в режиме модуляции добротности. Чтобы в полной мере использовать высокую термическую стойкость насыщающегося поглотителя на полированном волокне мы также 
демонстрируем переключение импульсов в режиме с нормальной полной дисперсией, для которого реализуется односолитонный режим при существенно больших энергиях. Мы считаем, что основным механизмом, обеспечивающим переключение, является модуляция нелинейного просветления насыщающегося поглотителя. Такие управляемые насыщающие поглотители могут использоваться как гибкий инструмент для исследования различных типов импульсной генерации, так и в индустрии для создания переключаемых лазеров или подбора оптимальных параметров насыщающегося поглотителя.

Работа выполнена при финансовой поддержке Российского научного фонда (No. 17-19-01787)

\section{Литература}

[1] S Kobtsev et. al., Optics Express 24, 28768 (2016)

[2] E. J. Lee et. al., Nature Communications 6, 6851 (2015) 